\title{
ARKEOLOGI PULAU TERDEPAN: TINJAUAN POTENSI PURBAKALA DI PULAU SELARU MALUKU TENGGARA BARAT \\ (Archaeology of Outermost Island: The Potential Overview in Selaru Island West Southeast Moluccas Indonesia)
}

\section{Marlon Ririmasse}

Balai Arkeologi Ambon Jl. Namalatu-Latuhalat, Ambon 97118

e-mail: ririmasse@yahoo.com

\section{INFO ARTIKEL}

\section{Histori artikel}

Diterima: 13 Juli 2016

Direvisi: 31 Agustus 2016

Disetujui: 14 Oktober 2016

\section{Keywords:}

Archaeology,

Outermost islands,

Selaru

\section{Kata kunci: \\ arkeologi, \\ pulau terdepan, \\ Pulau Selaru}

\begin{abstract}
Selaru is one of the 92 outermost islands in Indonesia. Geographically located in the Tanimbar Archipelago, Selaru is one of the southeastemmost island of Indonesia which is closely located to Australia. A condtion that present the strategic value in terms of politics and academics for this area. Unfortunately, despite the importance of this island, very limited archaeological and cultural historical study has been conducted in Selaru. This paper is a prelimenary overview of archaeological potential in one of the country frontline. The reconaissance survey has been adopted as an approach in this research. The results shows that Selaru is a potential region to be developed in the framework of archaeology and cultural history of the region. Includes, the cultural study to develop the border area of indonesia.
\end{abstract}

\begin{abstract}
ABSTRAK
Pulau Selaru adalah salah satu dari 92 pulau terdepan di Indonesia. Terletak di Kepulauan Tanimbar, Selaru menjadi salah satu pulau terselatan Nusantara yang paling dekat dengan daratan Australia. Hal mana memberi nilai strategis secara politis dan akademis bagi wilayah ini. Meski dengan nilai penting sedemikian, belum banyak perhatian dari studi arkeologi dan sejarah budaya bagi Pulau Selaru. Makalah ini merupakan tinjauan awal atas potensi arkeologi yang ada di salah satu wilayah teras negara ini. Pendekatan penelitian dilakukan dengan menggunakan metode survei penjajakan. Hasil studi menemukan bahwa Selaru memiliki potensi dalam kerangka studi arkeologi dan sejarah budaya kawasan. Termasuk dalam kaitan dengan kajian budaya untuk pengembangan kawasan perbatasan.
\end{abstract}

\section{PENDAHULUAN}

'Mohon bergeser ke tengah bapak-bapak', demikian kata-kata seorang awak kapal kepada kami. Serentak kami semua bergerak dari bibir atap kapal ke bagian tengah. Dengan gelombang yang cukup besar, terasa benar memang kemiringan kapal ini sedikit curam. Tak heran awak kapal harus mengingatkan kami yang duduk bergelanyut terlalu ke pinggir karena mempengaruhi keseimbangan kapal. Akses yang terbatas membuat transportasi bukanlah pilihan namun kewajiban untuk diterima apa adanya. Berisiko namun sampai di tujuan.

Saat itu tim penelitian kami berada di atas kapal motor penumpang
KM Engron dalam pelayaran dari Adaut, di Pulau Selaru, menuju Saumlaki, Ibu Kota Kabupaten Maluku Tenggara Barat, Propinsi Maluku, Indonesia. Setelah menyelesaikan penelitan hampir dua minggu di pulau ini. Berukuran tidak terlalu besar, kapal ini jauh dari nyaman tapi cukup baik untuk berlayar. Sehari-hari, Engron menjadi transportasi andalan bagi masyarakat yang bepergian dari dan ke Saumlaki dari Selaru. Termasuk bagi kami para pendatang.

Nama Egron sendiri diambil dari nama salah satu tanjung di utara Pulau Selaru, di Kepulauan Tanimbar. Titik yang terkenal bagi masyarakat karena di musim tenang selalu dibalut 
pemandangan indah. Namun saat lautan bergolak, para pelaut harus berhenti untuk menghormatinya. Butuh lebih dari dua jam bagi Engron untuk mengantar kami hingga merapat di pelabuhan tujuan.

Nama Selaru barangkali cukup asing. Bukan saja bagi mereka yang berasal dari luar, namun sering bagi orang Maluku sendiri. Hal ini dapat dimaklumi menimbang pulau ini bukanlah pulau utama serupa Ambon, Seram, Buru atau Kei. Selaru merupakan bagian dari Kepulauan Tanimbar dan menjadi pulau paling selatan di Kepulauan Maluku. Meski terletak paling jauh, Selaru adalah pulau yang memiliki nilai strategis bagi Propinsi Maluku dan negara Republik Indonesia bagi Maluku, Selaru adalah tapal batas darat paling selatan bagi propinsi ini. Bagi negara, Selaru adalah salah satu dari 92 pulau terdepan di Indonesia. Tapal batas daratan paling tenggara di Nusantara yang berbatasan dengan Australia.

Dengan peran sedemikian, Selaru sejatinya tak seasing namanya dalam pengelolaan kawasan perbatasan negara. Pulau ini menjadi bagian dari simpul-simpul geografi nasional yang membentuk teras terdepan negara. Maka wajar, ketika pemerintahan saat ini mendorong secara signifikan pengembangan kawasan perbatasan, Selaru juga menjadi bagian dari kebijakan strategis itu. Salah satu perkembangan yang paling kasat mata adalah kebijakan percepatan infrastruktur. Listrik kini telah menyala dengan leluasa di pulau ini. Jika pada tahun 2013 ketika penelitian ini dilaksanakan kondisi jalan antar desa masih sangat terbatas, maka kabar terakhir di media lokal memberitakan, bahwa tahun 2016 ini, jalan poros di Pulau Selaru akan mulai dibangun untuk menghubungkan desa-desa di wilayah ini Kondisi ini tentu perlu diapresiasi. Bukan rahasia lagi, bahwa Selaru, serupa pulaupulau kecil lain di kawasan perbatasan, telah sekian lama terpinggirkan dari perhatian pembangunan negara. Proses perkembangan berlangsung lambat. Letak yang terpencil dan akses yang minim tentu menjadi alasan. Kini keadaannya berbeda. Kebijakan Membangun dari Pinggiran oleh pemerintah saat ini diharapkan mampu menjadi motor yang menggerakan percepatan pembangunan di pulaupulau terluar ini termasuk di Selaru.

Hal yang kemudian perlu menjadi perhatian adalah, bahwa strategi pengembangan kawasan perbatasan selama ini cenderung melekat pada bidang-bidang seperti keamanaan, politik, infrastruktur, ekonomi, kesehatan dan pendidikan. Hal mana tentu bisa dipahami. Menimbang kebutuhan-kebutuhan dasar sebagaimana disebut tadi memang menyentuh langsung kepentingan masyarakat. Meski demikian tentu bukan alasan untuk tidak mendorong pembangunan aspek-aspek lain yang juga memiliki nilai penting bagi pengembangan masyarakat dan pengelolaan kawasan perbatasan. Serta memberi keseimbangan dalam pengembangan wilayah pulau terdepan. Salah satunya adalah pembangunan bidang kebudayaan.

Dengan geografi yang khas, kawasan tapal batas sejatinya merupakan gerbang bagi jati diri bangsa. Identitas sebagai bagian utuh dari Indonesia seharusnya melekat dengan erat di sini. Maka menempatkan kebudayaan masyarakat di kawasan perbatasan untuk berdiri sama tinggi dengan wilayah lain di negara kiranya 
merupakan sebuah kewajiban. Hanya dengan memberi tempat yang sejajar, hakekat sebagai anak bangsa dalam satu identitas nasional itu bisa diwujudkan.

Aktifitas penelitian budaya untuk menemukenali potensi kultural yang ada di wilayah perbatasan kiranya dapat menjadi salah satu jawaban untuk kondisi ini. Kehadiran kelompok peneliti budaya di wilayah-wilayah terbatas akses seperti pulau terdepan dapat dipahami masyarakat sebagai bentuk kepedulian negara untuk memuliakan kebudayaan setempat. Publikasi ilmiah yang memberi ruang yang setara dengan hasil kajian budaya di wilayah lain tentu akan menjadi kebanggaan tersendiri bagi mereka yang berdiam di wilayah perbatasan.

Hal ini kiranya yang kemudian menjadi salah satu alasan Balai Arkeologi Ambon untuk mendorong studi arkeologi di kawasan perbatasan di Maluku selama kurun waktu lima tahun terakhir. Tentu di samping alasan akademis-arkeologis untuk pulau-pulau ini (Ririmasse, 2010). Dengan jumlah pulau terdepan yang mencapai 18 pulau, pengelolaan kawasan perbatasan merupakan salah satu roh pengelolaan wilayah di Maluku. Aktivitas penelitian arkeologi dan sejarah budaya diharapkan dapat menjadi salah satu wahana untuk mendorong pembangunan bidang kebudayaan di pulau-pulau terdepan di Maluku termasuk di Selaru. Makalah ini merupakan hasil studi arkeologi di Pulau Selaru pada tahun 2013 dan bagian dari upaya untuk meluaskan pengetahuan terkait arkeologi pulaupulau terdepan di Maluku.

\section{Rumusan Masalah}

Pulau terdepan dan kawasan perbatasan senantiasa memiliki nilai penting dalam tata kelola kewilayahan negara. Keletakan pulau-pulau ini yang berada di kawasan lintas batas negara, telah memberi nilai strategis secara geopolitik dan geoekonomi. Dengan akses yang selama ini terbatas, pulau-pulau terdepan sejatinya juga merupakan lokus potensial bagi studi budaya. Salah satunya karena karakteristik potensi yang masih orisinil. Aktifitas penelitian budaya dipandang dapat menjadi cara untuk mendorong pembangunan kebudayaan di wilayah perbatasan. Termasuk di Maluku. Sebagai salah satu dari 18 pulau terdepan di Maluku yang berbatasan langsung dengan Australia, Pulau Selaru kiranya juga memiliki nilai strategis ditinjau dari studi arkeologi dan sejarah budaya. Utamanya dalam kaitan dengan upaya menjelaskan proses migrasi manusia dari Daratan Asia menuju Australia dan sebaliknya. Terkait dengan itu pada tahun 2013, Balai Arkeologi Ambon melakukan survei arkeologis untuk menemukenali potensi arkeologi yang ada di Selaru dengan permasalahan penelitian sebagai berikut:

1. Bagaimanakah potensi arkeologi dan kepurbakalaan yang ada di Pulau Selaru, Maluku Tenggara Barat?

2. Bagaimanakah kemungkinan aspek pengembangan untuk potensi ini ditinjau dari sisi akademis-arkeologis dan pengelolaan pulau terdepan?

\section{Metode}

Terkait dengan pertanyaan penelitian di atas maka upaya untuk menemukenali potensi arkeologi dalam kawasan penelitian merupakan basis dari kajian ini. Karena itu, pendekatan yang digunakan dalam penelitian ini adalah survei penjajakan dan studi pustaka. Survei penjajakan 
dilakukan untuk merekam potensi arkeologi langsung di lapangan secara verbal dan visual. Termasuk aspekaspek potensi yang terkait dengan masyarakat. Studi pustaka berfokus pada sumber-sumber terkait lokus penelitian serta referensi konseptual tentang pulau-pulau terdepan dan pengelolaan wilayah perbatasan.

Berpijak pada rumusan masalah di atas maka tujuan penelitian ini adalah:

1. Menemukenali potensi arkeologi dan kepurbakalaan yang ada di Pulau Selaru

2. Membuka ruang diskusi bagi kemungkinan pengembangan potensi ini ditinjau dari sisi akademis-arkeologis dan pengelolaan pulau terdepan.

\section{PEMBAHASAN}

\section{Kerangka Konseptual: Tinjauan \\ Pulau-Pulau di Kawasan \\ Perbatasan di Indonesia}

Upaya pengembangan dan percepatan pembangunan atas pulaupulau di kawasan perbatasan telah menjadi isu utama selama dekade terakhir. Dimana meski menjadi teras depan negara, kondisi pulau-pulau terdepan Nusantara kiranya masih jauh dari semestinya. Keterbatasan dan ketertinggalan senantiasa menjadi dua kata kunci untuk menggambarkan wajah pulau-pulau di kawasan perbatasan. Situasi ini ditunjukan dengan kondisi masyarakat di pulaupulau terdepan yang sebagian besar minimal secara ekonomi, memiliki mutu pendidikan rendah, seringkali lebih banyak bekerja di negara tetangga terdekat, rawan pangan, prevalensi berbagai penyakit yang tinggi, terisolasi dari pusat pertumbuhan ekonomi dan lekat dengan angka pengangguran di atas rata-rata (Zuhdi, 2006; Retraubun, 2006; Gesit, 2009; Ririmasse, 2010).

\section{Peraturan Presiden 78/2005}

kemudian diterbitkan sebagai kebijakan publik pertama yang mengatur upaya pengembangan wilayah perbatasan khususnya pulau terdepan. Kebijakan ini diharapkan dapat menjawab isu kesenjangan pembangunan, penegakan hukum, dan batas maritim di pulau-pulau terdepan yang mau diwujudkan benar-benar sebagai halaman depan NKRI.

Saat ini terdapat 92 pulau terdepan di Indonesia. Pulau-pulau ini berbatasan langsung dengan setidaknya sembilan negara tetangga mulai dari India di sebelah barat Aceh hingga Palau di utara Papua. Dari Sembilan negara yang berbatasan langsung ini, himpunan terbesar yaitu 23 pulau berbatasan dengan Australia, dilanjutkan dengan Malaysia (22 pulau), India (13), Filipina (11), Timor Leste (10), Palau (7), Singapura (4), Vietnam (2), dan 1 pulau dengan Papua Nieuw Guinea. Ke-92 pulau ini tersebar di 18 propinsi mulai dari Nangroe Aceh Darusallam hingga Papua (Ririmasse, 2010).

Selama ini perhatian atas pulau-pulau terdepan senantiasa dititikberatkan pada aspek politik dan pertahanan. Kemudian disusul oleh aspek ekonomi, transportasikomunikasi hingga kesehatan dan pendidikan. Situasi ini tentu dipahami, menimbang hal-hal yang dikedepankan tersebut terkait dengan kebutuhan dasar masyarakat dan negara. Meski demikian, rasanya perlu ditinjau kembali bahwa pulaupulau di kawasan perbatasan selain strategis dan potensial dari sisi geografis dan ekonomis, kawasan ini sejatinya juga memiliki profil budaya yang menjanjikan. Karakter sebagai kawasan tapal batas senantiasa memberikan warna tersendiri dalam profil budaya wilayah ini. Hal mana yang 
membuat pengelolaan aspek budaya kiranya juga perlu untuk diperhatikan.

Berpijak pada kondisi itu Pusat Penelitian Arkeologi Nasional telah mendorong pengembangan penelitian arkeologi di pulau-pulau terdepan dan kawasan perbatasan semenjak tahun 2010. Saat itu, bersamaan dengan Evaluasi Hasil Penelitian Arkeologi yang berlangsung di Yogyakarta. Pulau-pulau terdepan dan kawasan perbatasan dipandang memiliki nilai penting secara akademis dan nilai strategis dalam kerangka pengelolaan negara. Melalui aktifitas penelitian di pulau-pulau terdepan, potensi arkeologis yang ada di wilayah tapal batas ini dapat ditemukenali dan dikembangkan. Pada saat yang sama juga menciptakan ruang bagi kontribusi arkeologi nasional untuk pengembangan kawasan perbatasan.

Pada tahun yang sama Balai Arkeologi Ambon sebagai UPT Pusat Penelitian Arkeologi Nasional juga mulai menfokuskan kajian arkeologi di pulau-pulau terdepan di Maluku. Kondisi ini kiranya beralasan menimbang Propinsi Maluku dan Maluku Utara merupakan rumah bagi 19 dari 18 pulau terdepan yang ada di Indonesia. Dengan keletakan yang berbatasan langsung dengan Australia, pulau-pulau terdepan yang ada di Maluku sejatinya merupakan ranah terdepan untuk menjelaskan proses migrasi manusia masa lalu dan ruang aktifitasnya dalam kaitan dengan akses menuju daratan besar Australia (Birdsell, 1977; Spriggs, 1998; Tanudirdjo, 2005). Di sisi lain dari sudut pandang pengelolaan perbatasan, aktifitas penelitian arkeologi di pulaupulau terdepan merupakan bukti peran nyata BalaiArkeologi dalam mendorong pengembangan studi kebudayaan di wilayah tapal batas negara.
Dari 18 pulau terdepan yang ada di Maluku, sudah lima pulau yang ditinjau secara arkeologis. Di sini, aktifitas riset dilakukan dalam kerangka survei penjajakan untuk menemukenali potensi kepurbakalaan yang ada di pulau-pulau ini. Adapun keempat pulau terdepan yang telah dikaji secara arkeologis meliputi: Pertama, Pulau Kisar. Pulau ini merupakan bagian dari Kabupaten Maluku Barat Daya dan berbatasan langsung dengan Timor Leste. Survei arkeologis telah dilakukan di pulau ini pada tahun 2005 dan 2015. Hasil kajian awal pada tahun 2015 mengidentifikasi potensi arkeologis yang diwakili oleh jejak budaya kolonial meliputi benteng, struktur gereja tua; dan bekas bangunan sekolah Hindia Belanda. Sementara hasil survei kedua tahun 2015 mendata sebaran situssitus lukisan cadas dalam kawasan; Kedua adalah Pulau Lakor yang juga berbatasan langsung dengan Timor Leste. Survei arkeologis di pulau ini telah dilakukan pada tahun 2000 dan mengidentifikasi jejak pemukiman kuna dalam kawasan dengan penerapan tema perahu sebagai simbol; Ketiga adalah Pulau Larat yang merupakan bagian dari Kepulauan Tanimbar, Kabupaten Maluku Tenggara Barat. Survei arkeologis dilakukan pada tahun 2000 dan tahun 2014 dan merekam data arkeologi meliputi jejak pemukiman kuna dan penguburan sekunder di situs gua dan ceruk; Keempat adalah Pulau Yamdena yang terletak di Kepulauan Tanimbar, Kabupaten Maluku Tenggara Barat. Di sini diidentifikasi sebaran luas situs-situs pemukiman kuno dari masa prakolonial dengan tradisi megalitik berkarakter maritim yang masih difungsikan hingga saat ini (Ririmasse, 2008: 2011). Kelima, adalah Pulau Masela yang merupakan bagian dari Kepulauan Babar, Kabupaten Maluku Barat Daya. Di pulau ini diidentifikasi 
sebaran luas situs-situs pemukiman kuno masa prakolonial yang menjadi ciri khas pulau-pulau di belahan selatan Maluku. Di luar kelima rekam penelitian tadi, tahun 2013 Balai Arkeologi Ambon kembali melakukan studi arkeologis di pulau terdepan. Dengan lokus yang menjadi pilihan adalah Pulau Selaru yang menjadi fokus dari penulisan ini.

\section{Kepulauan Tanimbar dalam Rekam Studl Arkeologls}

Kepulauan Tanimbar secara administratif merupakan bagian dari Kabupaten Maluku Tenggara Barat dengan ibu kota, Saumlaki. Wilayah ini merupakan bagian dari Propinsi Maluku dan dibentuk sebagai kabupaten mandiri pada tahun 1999. Sebutan untuk Kepulauan Tanimbar sendiri mengacu kepada gugus pulau yang terletak di sebelah tenggara Kepulauan Banda. Geografi Kepulauan ini berbatasan dengan Kepulauan Kei di sebelah timur dan Kepulauan Babar di sebelah barat. Laut Banda menjadi pembatas di utara sementara Laut Arafura dan Australia menjadi pembatas di selatan.

Gugus Kepulauan Tanimbar dibentuk oleh lebih dari 174 pulau yang membentuk wilayah seluas 53, 251 $\mathrm{Km}^{2}$. Pulau terbesar dalam Kepulauan Tanimbar adalah Yamdena. Beberapa pulau utama lain adalah Selaru, Fordata, Wuliaru dan Sera. Pulau paling utara adalah Pulau Molu dan pulau paling selatan adalah Selaru. Pulau Selaru merupakan salah satu dari sembilan puluh enam pulau terluar di Indonesia (Ririmasse, 2010).
Gambar 1. Peta Pulau Selaru dalam Geografi Kawasan

(Sumber: Balai Arkeologi Ambon)

Dalambentangluaskepulauanini hidup lebih dari 100.000 jiwa penduduk. Mereka berbicara dalam lima bahasa berbeda. Bahasa dengan kelompok penutur terbesar adalah bahasa Yamdena, dilkuti bahasa Fordata, Bahasa Selaru, Bahasa Seluwasa dan Bahasa Makatian. Kelompok bahasa ini merupakan bagian dari rumpun bahasa Austronesia, Central Easter Malayo-Polynesian (Ririmasse, 2010a; Le Bar, 1976). Hampir seluruh penduduk di Kepulauan Tanimbar saat ini menganut agama Nasrani. Namun praktek-praktek religi lama masih dapat diamati dalam profil budaya tradisional masyarakat.

Sumber-sumber historis terkait Kepulauan Tanimbar umumnya dinisiasi oleh para pendatang Eropa (MicKinnon, 1988; de Jonge dan van Dijk, 1995; Miller, 2012). Mereka memiliki latar belakang petugas pemerintah kolonial hingga misionaris agama. J. G. F Riedel dan van Hoevell adalah dua nama yang cukup dikenal (Ririmasse, 2011). Kehadiran mereka terkait upaya menjalankan kebljakan pasiflkasi yang dlterapkan pemerintah kolonial Hindia Belanda di seluruh Kepulauan Maluku Tenggara. Riedel dan van Hoevel juga banyak 
menyumbangkan koleksi etnografi Tanimbarkemuseum-museumdiEropa. Beberapa objek bahkan ditampilkan sebagai bagian dari koleksi mahakarya di museum-museum terkemuka di Benua Biru. Misi Katolik masuk ke Tanimbar pada tahun 1907 sementara misi Protestan masuk setelah Perang Dunia ke-2. Di antara para misionaris yang datang, Petrus Drabbe adalah salah seorang yang paling menonjol. Kontribusi Drabbe bagi studi akademis di wilayah ini diwakili oleh karyanya terkait budaya Tanimbar yang berjudul Etnografie Tanimbar. Selepas Drabbe, nyaris tak ada karya akademik dengan bobot signifikan terkait Kepulauan ini. Sebelum akhirnya seorang antropolog asal Amerika Serikat, Susan McKinnon (1988), menerbitkan karyanya terkait studi antropologis atas wilayah ini dengan fokus pada Pulau Fordata.

Kondisi serupa juga ditemukan dalam konteks studi arkeologis yang masih cukup minimal dilakukan $\mathrm{di}$ wilayah ini. Beberapa penelitian telah dilaksanakan sebelumnya namun masih dalam bentuk tinjauan awal dengan fokus masalah dan wilayah kajian yang sangat terfragmentaris. Penelitian arkeologis paling awal di Kepulauan Tanimbar dilakukan oleh Intan (2004) yang merekam potensi sumber daya arkeologis di Sangliat Dol pada pertengahan dekade 1990 an. Penelitian berikutnya dilakukan oleh Wibawa (2002) yang meninjau fungsi monumen perahu batu di Sangliat Dol. Hal mana juga dilakukan oleh Sudarmika dalam perspektif yang lebih luas (Ririmasse, 2005). Dalam penelitian ini direkam jejak budaya berupa monumen perahu batu dan pemukiman tradisional. Tahun 2006 Ririmasse dan Sudarmika melakukan survei arkeologis di Pulau Selaru yang terletak di selatan Yamdena (Ririmasse, 2007a; 2007b).
Fokus penelitian diarahkan di sekitar kawasan situs Enus. Hasil pengamatan merekam keberadaan situs bekas pemukiman kuna dan sebaran tinggalan Jepang dari masa Perang Pasifik. Meski terbatas, himpunan tinjauan awal atas Kepulauan Tanimbar ini merupakan rujukan berarti sebagai landasan kajian lanjutan di wilayah ini.

Penelitian yang dilakukan pada tahun 2013 kali ini difokuskan pada pulau Selaru sebagai pulau paling selatan di Kepulauan Tanimbar. Lingkup kawasan yang ditinjau meliputi seluruh kawasan pulau ini. Pengamatan difokuskan pada desa-desa yang ada sebagai titik awal dengan berpijak pada informasi masyarakat dan datadata kajian dari sumber pustaka.

\section{Hasil Survei Arkeologis di Pulau Selaru}

Selaru adalah pulau yang terletak di selatan Yamdena. Pulau ini merupakan pulau terselatan di Kepulauan Tanimbar dan menjadi salah satu dari sembilan puluh dua pulau terdepan yang ada di Indonesia. Rekam studi arkeologis di pulau ini juga tergolong minim. Sumber terkait hanya diwakili oleh studi awal yang dilakukan Balai Arkeologi Ambon pada tahun 2006. Dalam kajian kali ini, survei dilakukan dengan cakupan yang lebih luas meliputi pengamatan atas titik-titik potensial yang terdapat di lima wilayah desa dari tujuh desa yang terdapat di pulau ini. Penanda paling khas dalam rekam sejarah di Pulau Selaru kiranya terwakili oleh keberadaan jejak tinggalan Perang Pasifik yang berlangsung antara tahun 1941-1945. Terkait dengan jejak pemukiman prakolonial sebagai fokus penelitian ini kiranya dapat diamati dari beberapa situs yang terekam dalam survei ini. 


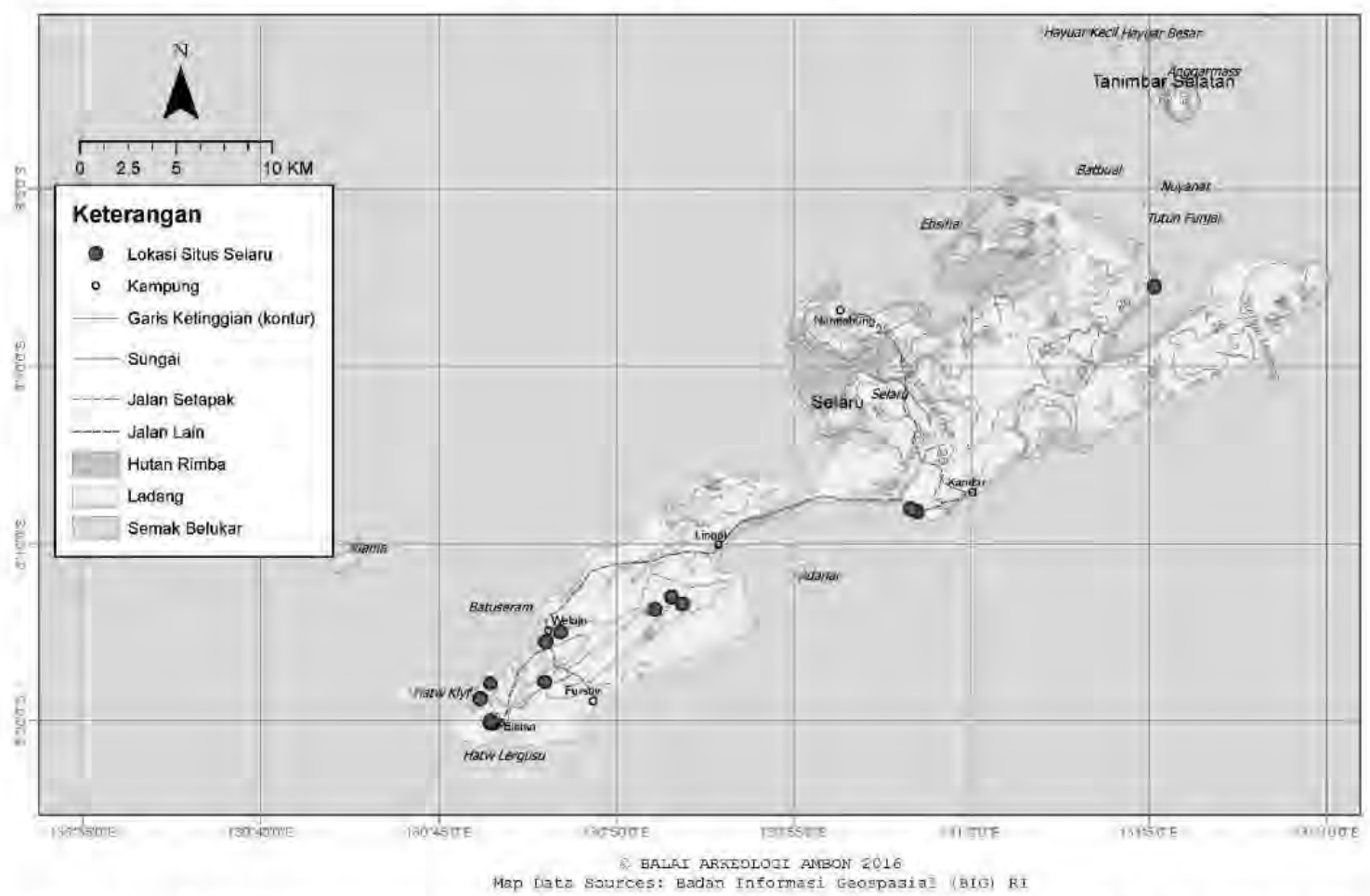

Gambar 2. Peta Sebaran Situs Arkeologi di Pulau Selaru (Sumber: Balai Arkeologi Ambon)

\section{Ceruk Eliasa 1}

Selaru adalah kawasan yang menjadi lokus utama dalam survei arkeologis di Kepulauan Tanimbar tahun 2013. Secara administratif Pulau Selaru merupakan satu wilayah administratif yang berada di bawah Kecamatan Selaru. Terdapat tujuh desa yang menjadi bagian dari wilayah administratif Kecamatan Selaru. Masing-masing, Desa Adaut, Desa Kandar, Desa Namtabung, Desa Lingat, Desa Weraing, Desa Fursui dan Desa Eliasa. Survei yang dilaksanakan kali ini meliputi enam desa di atas minus Desa Namtabung dan Desa Fursui.

Lokus pengamatan pertama adalah Desa Eliasa. Desa ini terletak di titik paling selatan di Pulau Selaru. Ceruk Eliasa 1 terletak pada koordinat S $\quad 08^{\circ} 20.077^{\prime}$ E $130^{\circ} 46.531^{\prime}$. Menimbang posisi Selaru sebagai salah satu dari sembilan puluh dua pulau terdepan di Nusantara, dapat dikatakan Eliasa merupakan salah satu desa di tapal batas Nusantara.

Titik pengamatan pertama di Desa Eliasa adalah kompleks ceruk gamping yang berada di perbukitan sebelah timur desa. Ceruk ini berada dalam satu arah dengan jalan setapak dari desa menuju kompleks pemukiman kuna Negeri Lama Eliasa. Karakteristik ceruk ini ditandai dengan bentang dinding batu gamping sepanjang lebih dari dua ratus meter dengan tinggi mencapai sekitar enam meter. Di sekitar ceruk ini kini dimanfaatkan sebagai lahan kebun oleh masyarakat setempat.

Pengamatan yang dilakukan di sekitar area ceruk menemukan jejak artefaktual berupa fragmen gerabah polos berwarna coklat gelap. Temuan lain diwakili oleh sebaran moluska yang tersebar secara merata di sekitar situs ini. Menimbang kondisi temuan yang cukup minim, disimpulkan bahwa titik ini kurang potensial untuk ditindaklanjuti. 


\section{Negeri Lama Eliasa}

Titik pengamatan kedua di Desa Eliasa adalah kawasan pemukiman kuna yang oleh masyarakat setempat dikenal dengan nama Negeri Lama Eliasa. Negeri Lama Eliasa terletak pada koordinat S $08^{\circ} 20.070^{\prime} \mathrm{E} 130^{\circ}$ 46.447'. Situs ini berada di kawasan perbukitan di sebelah barat Desa Eliasa. Jarak antara dari Desa Eliasa ke Situs diperkirakan sekitar dua kilometer. Sumber sejarah tutur yang disampaikan oleh para tetua adat menyebutkan bahwa kawasan negeri lama ini merupakan titik hunian pertama oleh para leluhur yang mendiami Desa Eliasa.

Karakteristik situs ini kiranya serupa dengan situs-situs negeri lama yang ada di Kepulauan Tanimbar dan Kepulauan Maluku Tenggara secara umum. Kondisi ini dapat diamati dari keletakan situs yang berada di dataran tinggi di kawasan perbukitan. Akses menuju situs ini juga minimal sebagaimana ditandai dengan topografi di sekeliling kawasan situs yang cukup curam. Pananda ketiga adalah keberadaan tembok keliling yang memperkuat karakter defensif dari situs ini. Negeri lama Desa Eliasa juga memiliki tembok keliling yang dibentuk dari susunan batu gamping terumbu dengan tinggi sekitar tiga meter dan tebal susunan batu sekitar hampir dua meter.

Saat ini kawasan negeri lama ini telah dimanfaatkan oleh penduduk sebagai lahan kebun. Meski demikian nilai sakral dari situs ini tetap dipertahankan. Kondisi ini dapat diamati dari ritual yang harus dilalui oleh tim Balai Arkeologi Ambon sebelum memasuki lokasi situs. Hasil pengamatan yang dilakukan di lokasi negeri lama menemukan sebaran fragmen gerabah polos dan berhias. Jejak artefaktual juga diwakili oleh fragmen keramik asing. Selain tinggalan artefaktual, sebaran moluska juga ditemukan dalam jumlah melimpah secara merata di dalam kawasan situs. Ditinjau karakteristik situs dan sebaran temuan yang cukup padat, dapat disimpulkan situs ini cukup potensial untuk ditindaklanjuti dengan kegiatan ekskavasi untuk menemukan jejak lapisan budaya yang lebih awal.

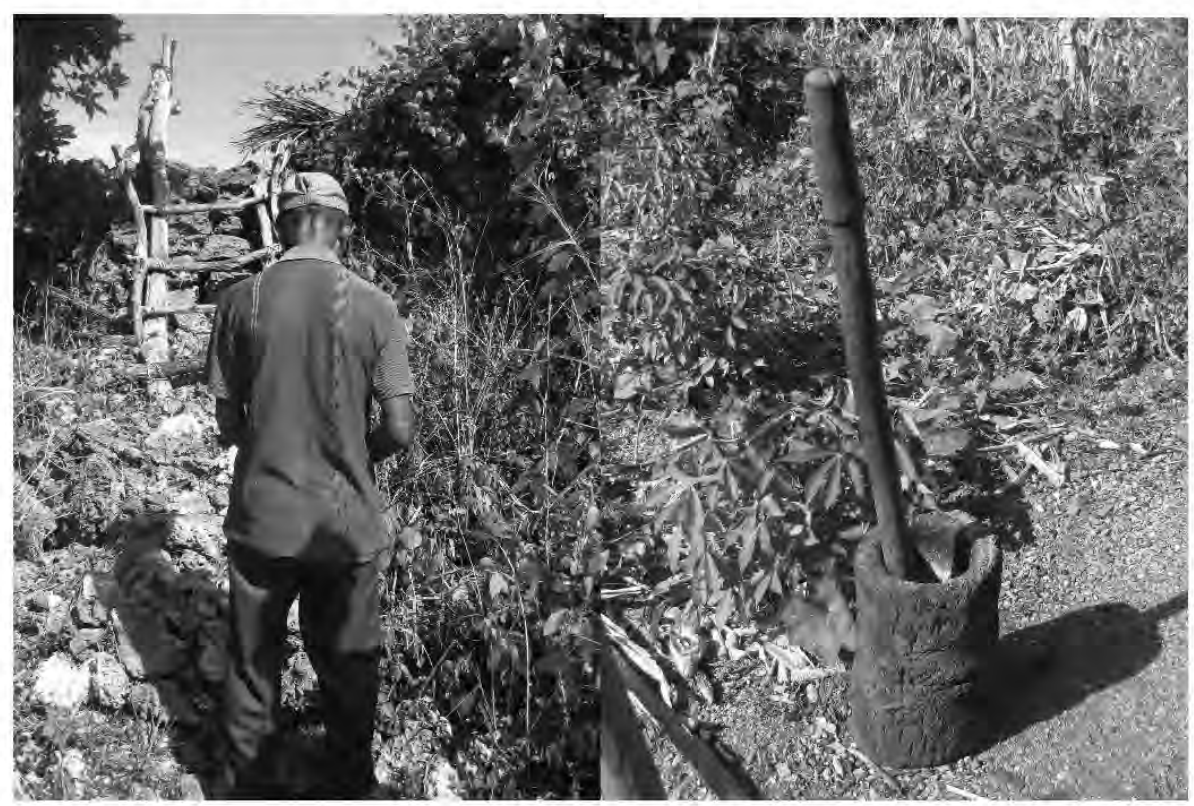

Gambar 3. Tetua adat Memanjatkan Doa di Depan Pintu Masuk Negeri Lama Eliasa dan Lesung Tradisional di Kebun Penduduk (dokumentasi Balai Arkeologi Ambon) 


\section{Kompleks Gua Hoas Nugebusu}

Kawasan perbukitan di sebelah barat Desa Eliasa memang memiliki karakteristik sebagai kawasan karst. Kondisi ini kiranya dapat diamati dari keberdaaan kompleks gua yang berada dalam kawasan perbukitan ini. Pengamatan yang dilakukan oleh tim Balai Arkeologi Ambon juga meninjau kompleks gua ini. Pengamatan atas kompleks gua dilakukan untuk meninjau potensi gua dalam kaitan dengan aktivitas sebagai hunian masa lalu.

Lokus gua yang dikunjungi bernama Hoas Nugebusu. Kompleks Gua Hoas Nugebusu terletak pada koordinat S $8^{\circ} 20.017^{\prime} \mathrm{E} 130^{\circ} 46.465^{\prime}$. Kompleks gua ini terletak di sebelah utara kawasan pemukiman kuna Negeri Lama Eliasa. Karateristik Kompleks Gua Hoas Nugebusu adalah kawasan dengan hampir selusin gua. Tidak termasuk ceruk-ceruk yang mengelilingi kawasan ini. Umumnya hampir seluruh gua memiliki karakter sebagai gua horizontal dengan lebar pintu mencapai dan tinggi pintu beragam. Beberapa bahkan sangat tinggi dan lapang. Ruang di dalam gua-gua ini juga terbagi atas banyak bilik. Kondisi lantai gua-gua yang ada di kompleks Hoas Nugebusu umumnya memiliki sedimen yang cukup tebal dengan kondisi kering.

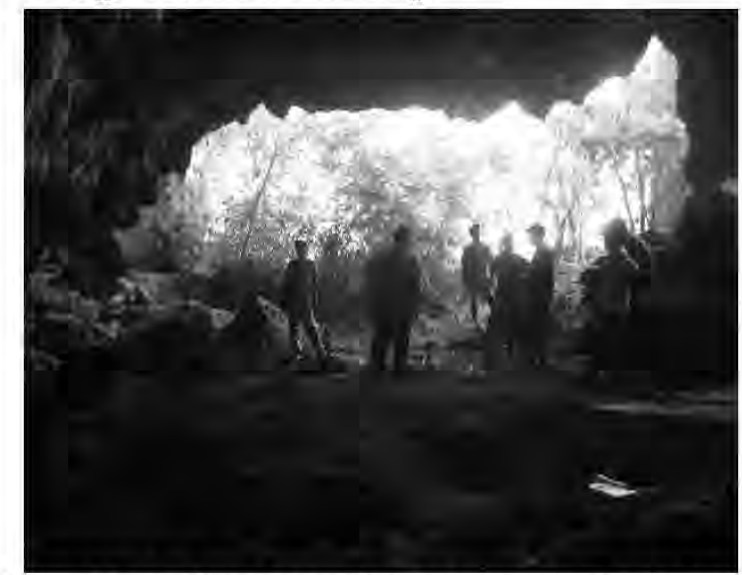

Gambar 4. Gua Hoas Nugebusu 1 di Desa Eliasa (dokumentasi Balai Arkeologi Ambon)
Hasil pengamatan yang dilakukan di beberapa gua menemukan sebaran fragmen gerabah polos dan keramik asing. Ditemukan juga struktur kongkrit yang menurut informasi penduduk dibangun oleh tentara Jepang selama masa Perang Dunia ke-2. Selain itu hasil pengamatan juga menunjukan kondisi gua yang sudah cukup terdistorsi. Meski demikian hasil pengamatan menunjukan bahwa gua ini cukup layak untuk dikaji lebih lebih lanjut melalui kegiatan ekskavasi untuk menemukan kemungkinan jejak hunian yang lebih awal.

\section{Gua Hoas Nugebusu 2}

Gua Hoas Nugebusu 2 terletak pada koordinat $S \quad 08^{\circ} 20.021^{\prime} \mathrm{E}$ $130^{\circ} 46.465^{\prime}$, berada dalam kawasan perbukitan karst di sebelah barat Desa Eliasa. Gua ini terletak di sebelah barat Gua Hoas Nugebusu. Oleh tim, titik pengamatan ini kemudian disepakati untuk diberi nama Gua Hoas Nugebusu 2. Karakter khas dari gua ini adalah ukurannya yang luas. Pintu gua ini mencapai tinggi 11 meter dan lebar 8 meter dengan bilik gua yang sangat lapang. Terdapat rongga di langit-langit gua sehingga cahaya matahari dapat langsung menembus ke dalam bilik gua. Dengan profil yang sedemikian pencahayaan di dalam gua ini cukup baik dengan sirkulasi udara yang juga baik. Kondisi lantai gua memiliki sedimen yang cukup tebal dan kering.

Hasil pengamatan yang
dilakukan di dalam bilik gua menemukan jejak artefaktual berupa fragmen tembikarpolos berwarna coklat kehitaman. Fragmen keramik asing juga ditemukan meski dalam jumlah yang cukup terbatas. Di bagian pintu gua terdapat susunan batu gamping terumbu yang agaknya disusun sebagai pelindung. Hasil pengamatan yang dilakukan di gua ini memberi 
kesimpulan bahwa gua Hoas Nugebusu 3 cukup potensial untuk ditindaklanjuti melalui kegiatan ekskavasi arkeologis untuk menemukan kemungkinan jejak hunian yang lebih awal.

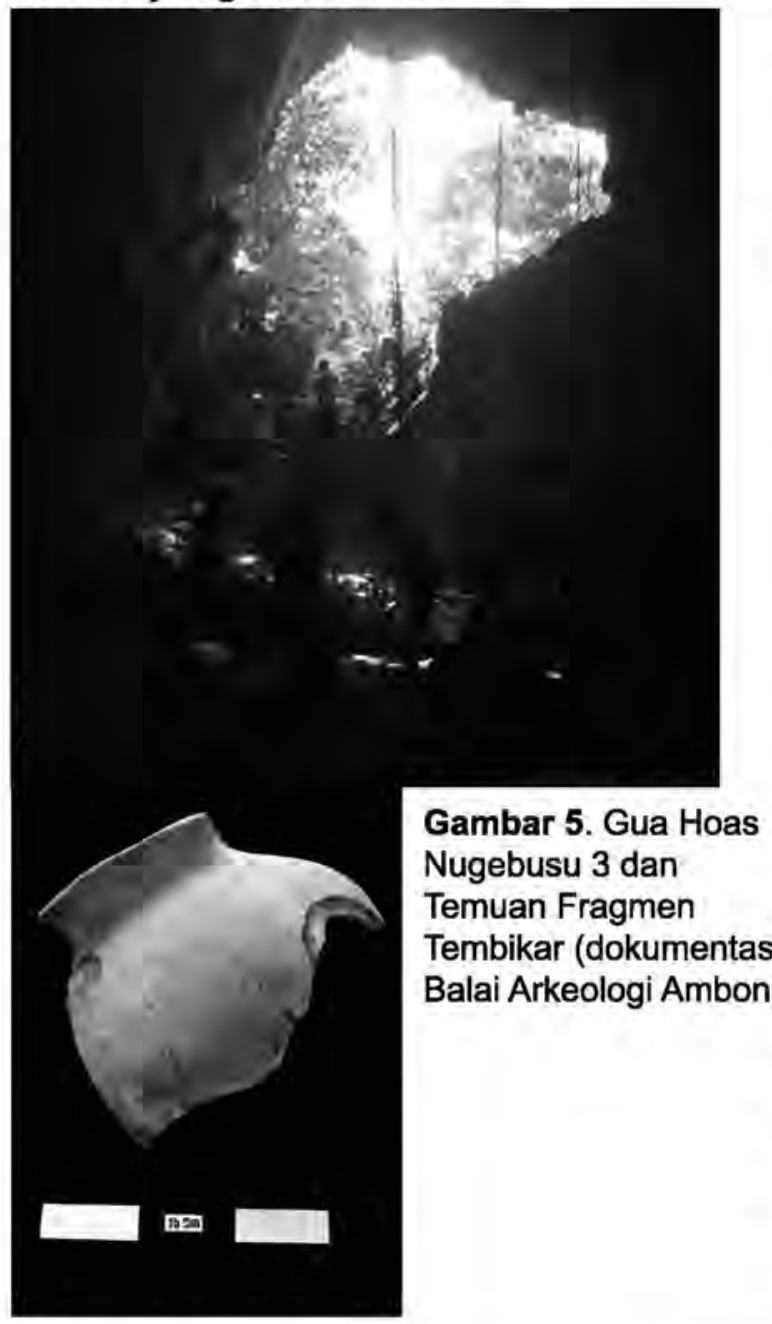

\section{Ceruk Arousu}

Titik pengamatan selanjutnya adalah ceruk Arousu yang terletak di pesisir barat Desa Eliasa. Ceruk Arousu terletak pada koordinat $S$ $08^{\circ} 19.383^{\prime}$ E $130^{\circ} 46.165^{\prime}$. Ceruk ini berada kurang lebih 400 meter dari bibir pantai. Secara administratif titik ini masih menjadi bagian dari wilayah Desa Eliasa.

Ceruk ini merupakan bagian dari kawasan gamping yang membentang dari lereng perbukitan bagian barat Desa Eliasa. Kondisi ceruk ini ditandai dengan sisi depan yang sudah tertutup oleh semak-semak.
Hasil pengamatan di dalam gua menemukan jejak berupa himpunan cranium (tengkorak) sebanyak 14 buah. Tengkorak-tengkorak ini tidak mengumpul namun menyebar di lantai ceruk. Kondisi tengkorak hampir sebagian besar utuh. Selain tengkorak tidak ditemukan indikasi artefaktual. Bercermin pada temuan yang ada diperkirakan situs ini merupakan situs penguburan sekunder di masa lalu.

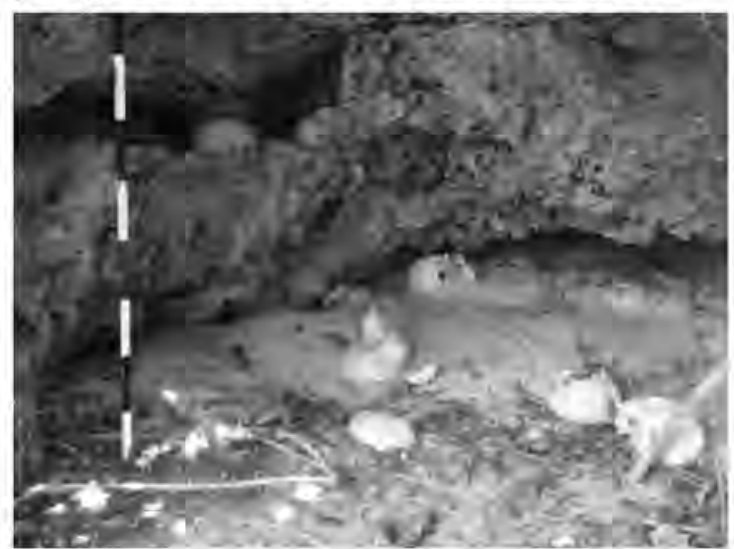

Gambar 6. Ceruk Arousu di Desa Eliasa dengan sebaran cranium

(dokumentasi Balai Arkeologi Ambon)

\section{Ceruk Eliasa 2}

Titik pengamatan ke-10 ini berada di bagian utara Desa Eliasa. Tepat berada pada wilayah tapal batas antara Desa Eliasa dan Desa Weraing. Ceruk Eliasa 2 terletak pada koordinat $S \quad 08^{\circ} 18.939^{\prime} E$ $130^{\circ} 46.465$ '. Karakteristik lokus ini ditandai oleh keberadaan bentang dinding batu gamping yang merupakan perpanjangan dari perbukitan di sebelah timur. Lokus ini berada kurang lebih $\mathbf{3 0 0}$ meter dari bibir pantai.

Hasil pengamatan di sekitar lokasi situs ini menemukan jejak artefaktual berupa sebaran fragmen gerabah polos. Termasuk pecahan tempayan dalam ukuran yang cukup besar.

\section{Negeri Lama Laloan}

Titik pengamatan selanjutnya di Desa Weraing adalah lokasi pemukiman kuna yang disebut 
sebagai Negeri Lama Laloan. Lokus ini terletak di sebelah tenggara Desa Weraing. Jarak dari lokus ke bibir pantai kurang lebih satu kilometer. Negeri Lama Laloan terletak koordinat S $\quad 08^{\circ} 18.894^{\prime} \mathrm{E}$ $130^{\circ} 47.975^{\prime}$. Karakteristik lokus Negeri Lama Laloan kiranya serupa dengan situs-situs pemukiman kuna yang ada di Kepulauan Tanimbar. Keletakan situs ini berada di dataran yang relatif lebih tinggi dibanding kawasan sekitamya. Saat tim melakukan pengamatan akses menuju lokus ini juga cukup minimal. Penanda khas lainnya adalah keberadaan tembok keliling yang dibentuk dari susunan batu gamping terumbu. Tinggi tembok keliling di situs ini mencapai satu setengah meter dengan ketebalan hingga satu meter. Pengamatan yang dilakukan di sekitar lokasi situs menemukan indikasi artefaktual berupa fragmen gerabah polos dan fragmen keramik asing.

\section{Keramat Marga Lamerburu}

Serupa dengan keramat milik warga Silaloin, keramat ini juga merupakan tempat untuk meletakan kepala musuh yang dipenggal saat pertempuran dan perang. Titik ini terletak di salah satu ceruk dinding gamping yang berada di sebelah tenggara Desa Weraing. Keramat Marga Lamerburu terletak pada koordinat S $08^{\circ} 17.749^{\prime}$ E $130^{\circ}$ 48.017'. Titik pengamatan selanjutnya adalah keramat milik Marga Lamerburu. Hasil pengamatan menemukan himpunan tengkorak yang tersebar di sekitar lokus ini sebagai indikasi praktek pengayauan dalam perang masa lalu yang disebutkan penduduk. Jejak artefaktual yang teramati adalah keberadaan fragmen keramik asing(keramik Chin)serta fragmen gerabah yang ditemukan berasosiasi dengan himpunan tengkorak.

Gambar 7. Keramat di Negeri Lama Marga Lamerburu dengan Ternuan Fragmen Keramik Asing dan Cranium (dokumentasl Balal Arkeolog| Ambon)

Negerl Lama Serintun

Lokus yang menjadi titik pengamatan terakhir di desa Weraing adalah kompleks pernukiman kuna Negeri Lama Serintun. Situs ini berada di sebelah timur laut Desa Weraing. Sebagaimana halnya situssitus pemukiman kuna di Kepulauan Tanimbar, situs ini juga terletak di dataran tinggi, tepat di atas kawasan bukit batu gamping. Negeri Lama Serintun terletak pada koordinat S $08^{\circ} 17.484^{\prime} \mathrm{E} 130^{\circ} 48.430^{\prime}$. Posisi pemukiman ini cukup strategis karena menempati titik tertinggi dalam perbukitan sekitar kawasan. Dari titik ini, bisa diamati bentang pesisir barat pulau Selaru yang luas. Akses menuju kawasan pemukiman kuna juga cukup minim. Hanya ada satu jalan setapak yang digunakan untuk mencapai situs. Kawasan sekeliling situs memiliki topografi yang curam dan berbatu. $\mathrm{Di}$ sepanjang lokasi pemukiman kuna, dibangun pagar pembatas dari susunan batu gamping terumbu. Kondisi ini kembali mempertegas karateristik defensif yang ada pada situs-situs pemukiman kuna yang ada di wilayah ini. Saat ini lokasi pemukiman kuna ini telah dimanfaatkan penduduk sebagai lahan kebun. Hasil pengamatan yang dilakukan di lokasi situs menemukan jejak artefaktual berupa sebaran fragmen gerabah dan fragmen keramik asing dalam jumlah yang cukup banyak. 


\section{Negeri Lama Enus}

Umumnya seluruh masyarakat dalam lingkup Kepulauan Tanimbar mengenal Negeri Enus. Sejarah tutur di wilayah ini meyakini bahwa Enus merupakan sebuah kerajaan besar di masa lalu. Adalah dari Negeri Enus inilah leluhur dari seluruh komunitas yang ada saat ini di Tanimbar diyakini berasal. Enus kini merupakan kawasan pemukiman kuna yang telah ditinggalkan. Negeri Lama Enus terletak S $08^{\circ} 16.837^{\prime} \mathrm{E} 130^{\circ}$ $51.090^{\prime}$. Lokus ini secara administratif merupakan bagian dari Desa Lingat. Jarak dari Desa Lingat menuju Situs Enus adalah sekitar lima kilometer.

Serupa dengan negeri-negeri lama lainnya di Kepulauan Tanimbar, Situs Enus juga terletak di kawasan dataran tinggi. Situs ini berada pada salah satu puncak di kawasan karst di tengah pulau Selaru. Dibanding lingkungan sekitarnya yang relatif rendah, Enus memang nampak kontras dan menonjol. Bagian sekeliling kawasan pemukiman terdiri dari dinding terjal. Akses menuju daerah datar di puncak yang menjadi lokasi pemukiman juga minimal. Di sekeliling situs ini nampak disusun batu-batu sebagai pembatas dan pelindung.

Kawasan pemukiman berada di bagian puncak yang datar. Luas kawasan ini mencapai lebih dari 1,000 meter persegi. Pengamatan yang dilakukan di dalam lingkungan bekas pemukiman menemukan sebaran fragmen gerabah dan keramik asing dalam jumlah yang cukup besar dan merata. Nampak beberapa batu dalam ukuran besar di tengah kawasan yang oleh penduduk setempat diidentifikasi sebagai titik dimana raja Enus dulunya berdiam.
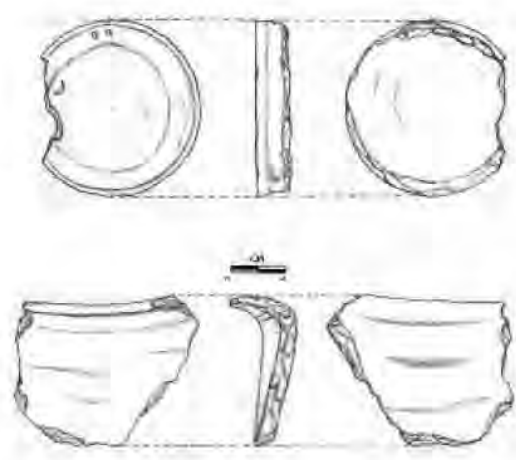

Gambar 8. Sketsa Fragmen Tembikar Polos di Situs Enus

(dokumentasi Balai Arkeologi Ambon)

Penanda khas lain di situs ini adalah keberadaan himpunan fragmen tengkorak yang diletakan di relungrelung dinding cadas yang curam di sekeliling kawasan situs. Saat pengamatan dilakukan setidaknya terdapat lebih dari sepuluh tengkorak dalam relung-relung dinding cadas. Pengamatan yang dilakukan di kawasan sekitar situs juga menemukan fragmen gerabah polos dan berhias serta keramik asing dalam jumlah yang cukup banyak. Ditinjau dari karakteristik lingkungan situs, Negeri Lama Enus cukup layak untuk ditindaklanjuti melalui ekskavasi arkeologis untuk menghimpun data kronologi situs.



Gambar 9. Penguburan Sekunder di Ceruk yang umum ditemukan di situs-situs pemukiman kuno di Kepulauan Tanimbar (dokumentasi Balai Arkeologi Ambon) 


\section{Gua Usbob}

Sekitar 500 meter ke arah utara Gua Usher yang kurang potensial, terdapat titik pengamatan berikut yang dikenal oleh masyarakat sebagai Gua Usbob. Gua ini masih berada dalam satu kawasan dengan Gua Usher sebagaimana ditandai dengan karakteristik lingkungan karst untuk kedua lokus ini. Gua Usbob terletak pada koordinat S $08^{\circ} 16.501^{\prime} \mathrm{E} 130^{\circ}$ 51.557'. Serupa dengan Gua Usher, Gua Usbob juga berada sedikit di bawah permukaan tanah dataran sekitarnya.

Gua Usbob merupakan gua horizontal. Pintu Gua menghadap ke barat dengan pencahayaan yang cukup baik. Lebar pintu gua adalah 9 meter dengan tinggi mencapai 4 meter. Panjang lorong gua mencapai 21 meter dengan beberapa bilik kecil di dalam. Hasil pengamatan yang dilakukan di dalam bilik gua menemukan himpunan fragmen gerabah polos dalam berbagai ukuran. Fragmen keramik asing dan botol Eropa juga ditemukan. Melalui pengamatan yang dilakukan dalam bilik gua menunjukan gua ini potensial untuk ekskavasi.

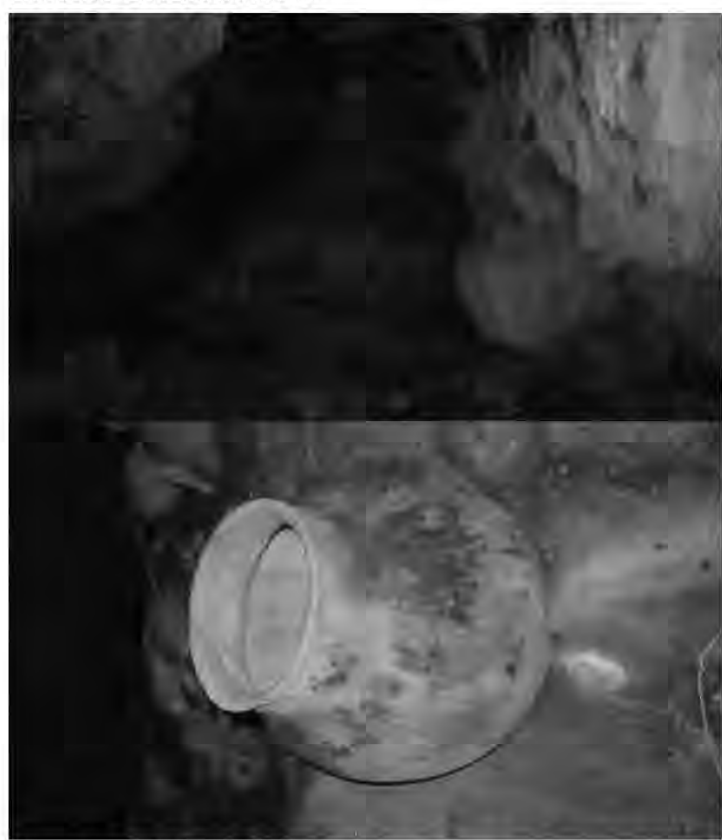

Gambar 10. Gua Usbob di Desa Lingat dan Temuan Bejana Tembikar Polos (dokumentasi Balai Arkeologi Ambon)

\section{Negeri Lama Lakmodat}

Kawasan Pemukiman Kuna lain yang ditinjau dalam survei ini adalah Negeri Lama Lakmodat. Titik ini terletak di sebelah selatan Desa Lingat, pada koordinat S $08^{\circ} 16.689^{\prime} \mathrm{E} 130^{\circ} 51.849^{\prime}$. Kurang lebih satu jam perjalanan jalan kaki. Serupa dengan Negeri Lama Enus, Lakmodat juga terletak di ketinggian. Tepat di sebuah perbukitan gamping. Akses menuju situs cukup terbatas, menimbang lingkungan sekeliling situs bertopografi curam. Susunan batu sebagai pembatas dan tembok keliling juga teramati yang memperkuat kesan defensif pada sebuah pemukiman kuna di pulaupulau selatan Maluku. Lokus bekas pemukiman kuna terletak di kawasan puncak perbukitan yang datar.

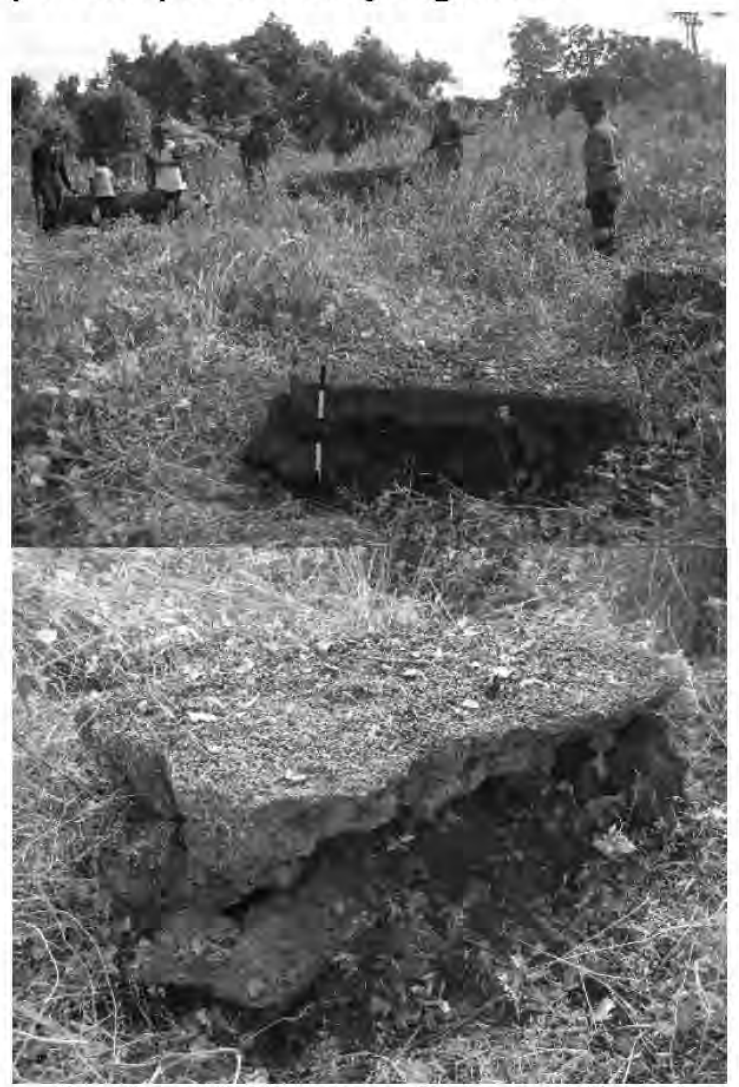

Gambar 11. Himpunan Dolmen di Negeri Lama Lakmodat (dokumentasi Balai Arkeologi Ambon)

Hasil pengamatan di situs ini menemukan himpunan dolmen yang dikonfigurasi mengelompok. Tiga buah dolmen ditata dengan orientasi 
utara-selatan, sementara dua dolmen lainnya ditata dengan orientasi menghadap timur-barat. Dimensi setiap dolmen hampir sama. Tiga dolmen masih dalam kondisi utuh dan tegak, sementara dua buah dolmen lain sudah lepas dari penyangganya. Menurut informasi penduduk setempat, sejarah tutur menyebutkan bahwa dolmen-dolmen ini merupakan tempat duduk bagi para tetua desa di masa lalu untuk berkumpul dan bermusyawarah. Pengamatan yang dilakukan di dalam lingkungan situs tidak menemukan indikator artefaktual lain.

\section{Ceruk Sendul 1}

Bergerak ke sebelah selatan tim menemukan kawasan kompleks gua yang oleh penduduk setempat disebut sebagal Gua Sendul. Terletak pada koordinat S $08^{\circ} 14.085^{\prime} \mathrm{E} 130^{\circ} 58.485^{\prime}$. Secara umum kompleks gua ini meliputi area yang cukup luas dengan topografi yang bervariasi. Karakteristik sebagai kawasan karst sangat terlihat dari morfologi lingkungan yang kaya dengan gamping dengan relung dan ceruk.

Titik pengamatan yang direkam adalah SLR-27 yaitu sebuah ceruk kecil dalam kompleks luas ini. Ceruk ini merupakan ceruk vertikal dengan ukuran yang kecil. Lebar ceruk hanya sekitar $80 \mathrm{~cm}$ dengan tinggi sekitar 1 meter. Di relung ini ditemukan lima tengkorak tanpa jejak artefaktual lainnya. Tidak ada informasi terkait himpunan tengkorak ini yang diberikan oleh pemandu dan penduduk sekitar. Agaknya tengkorak-tengkorak initerkait praktek penguburan tradisional yang umum dikenal di wilayah Kepulauan Tanimbar atau kepala musuh korban perang yang diletakan dalam relungrelung batu.
Kompleks Weslyeta

Titik pengamatan yang paling memilki nilai potensi tinggi kiranya diwakili oleh lokus ke-34 yang oleh penduduk setempat disebut sebagai kawasan Negeri Lama Wesliyeta. Terletakpadakoordinat S $08^{\circ} 14.020^{\prime} E$ $130^{\circ}$ 58.312'. Sejarah setempat menyebutkan dahulu kawasan ini merupakan pemukiman kuna dari komunitas Wesliyeta. Menyusul konflik dengan komunitas lain dalarn kawasan, Weliyeta kalah dalam perang sehingga harus bermigrasi ke pesisir selatan Pulau Yamdena. Saat ini terdapat kampung dengan nama sama di pesisir selatan Yamdena, pulau terbesar di Kepulauan Tanimbar.

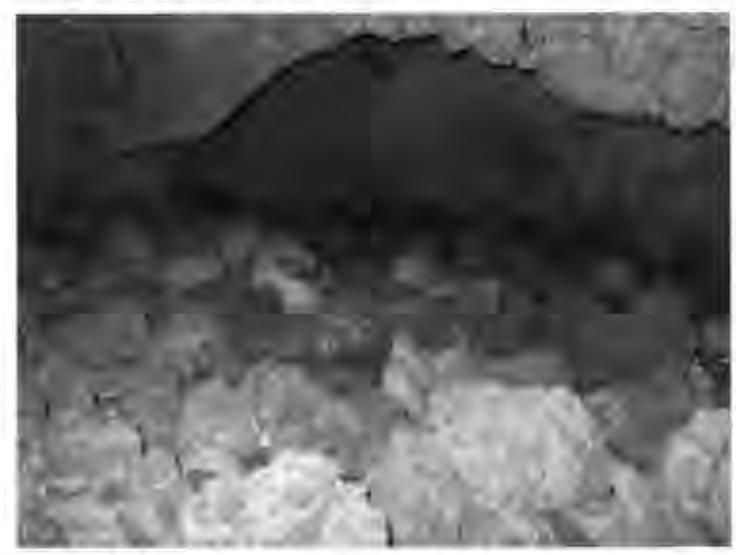

Gambar 12. Himpunan Cranium di Salah Satu Billk Ceruk Weslieta di Kandar (dokumentasl Balal Arkeologl Ambon)

Penanda paling khas pada lokus ini adalah keberadaan penguburan massal yang berada di Gua dan Ceruk. Gua dan ceruk ini berada pada salah satu relung kawasan karst yang berada lebih rendah dari dataran di sekitarnya membentuk konfigurasi melingkar. Di bagian barat laut terdapat gua dengan ukuran pintu sekitar 3 meter dan tinggi mencapai 2 meter. Dalam gua ini ditemukan himpunan tengkorak berjumlah puluhan beserta ragam fragmen gerabah dan keramik asing. Di sepanjang sisi barat juga terdapat sebaran tengkorak dan beberapa 
fragmen tulang lainnya. Bagian yang dipandang paling menarik adalah keberadaan sebuah gua di sisi selatan dengan pintu masuk sempit setinggi $40 \mathrm{~cm}$. Panjang gua kecil ini mencapai sekitar 4 meter. Di dalam gua inilah terdapat puluhan tengkorak dan fragmen gerabah, keramik asing dan gelang berbahan kerang atau dalam bahasa Tanimbar biasanya disebut sebagai Belusu.

Ragam jejak serupa juga ditemukan di dalam kompleks ini. Jika diamati lapisan sedimen di gua ini cukup tipis namun kiranya cukup memadai untuk aktivitas ekskavasi. Tidak ada informasi penduduk terkait sejarah tutur yang bisa menjelaskan peran situs ini dan asal muasal ratusan tengkorak yang tersebar di situs ini. Ditinjau dari kompleksitas profilnya titik pengamatan ini dipandang potensial untuk dikaji lebih lanjut melalui ekskavasi arkeologis guna menghimpun data kronologi situs.

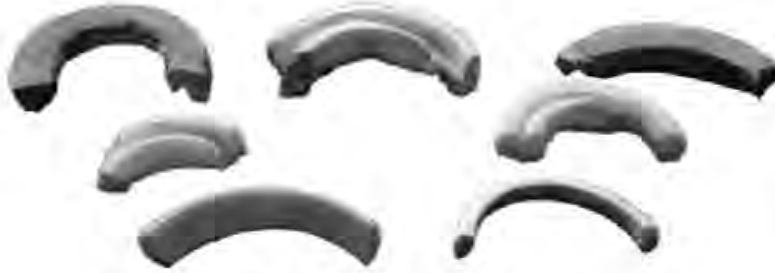

Gambar 13. Fragmen Belusu (Gelang Kerang) khas Tanimbar yang biasanya dibuat dari Kerang Tridacna atau serupa yang ditemukan dalam asosiasi dengan himpunan cranium di Situs Weslieta (dokumentasi Balai Arkeologi Ambon)

\section{Ceruk Kora}

Ceruk ini terletak pada kawasan karst yang membentang sepanjang pesisir semenanjung Fulmanan di sebelah barat Desa Adaut, yaitu pada koordinat S $08^{\circ} 07.758^{\prime} \mathrm{E} 131^{\circ} 05.155^{\prime}$. Dari Adaut titik pengamatan ini dapat dicapai dengan menggunakan motor laut selama kurang lebih dua puluh menit. Karakteristik lingkungan kawasan ini ditandai dengan hamparan dinding gamping terumbu yang membentang lebih dari dua kilometer. Nampak ceruk, relung dan takik di sepanjang kawasan ini yang memberi nuansa kompleks bagi lingkungan khas ini. Di sebelah atas kawasan ini kini dipergunakan oleh penduduk sebagai kebun.

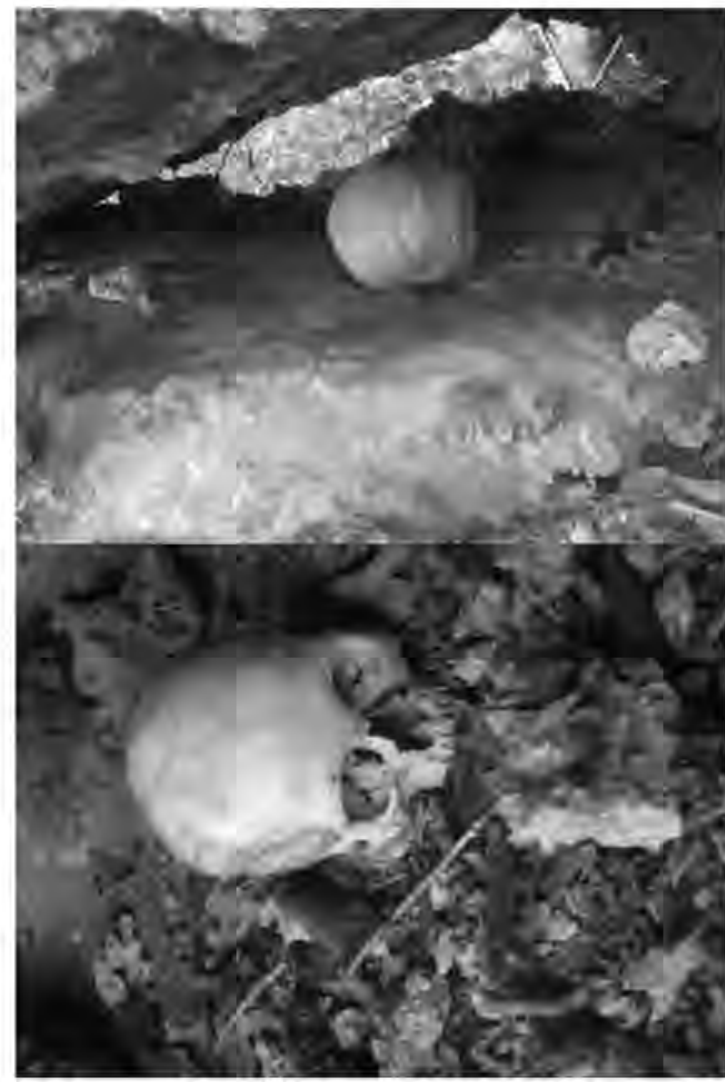

Gambar 14. Temuan Cranium sebagai

Penanda Penguburan Sekunder di Situs Negeri Lama Kora di Adaut

(dokumentasi Balai Arkeologi Ambon)

Hasil pengamatan yang dilakukan di sepanjang ceruk Kora yang membentang di pesisir menemukan sebaran tengkorak yang tersebar secara merata. Beberapa tengkorak nampak masih utuh, sementara beberap tengkorak lain hanya tingga fragmennya saja. Informasi penduduk menyebutkan bahwa di bagian utara semenanjung ini juga terdapat lokus penguburan tradisional serupa. Hasil pengamatan yang dilakukan oleh tim tidak menemukan indikasi artefaktual yang menyertai himpunan tengkorak ini. 


\section{Karakter Situs-Situs Arkeologi Potensial di Pulau Selaru}

Hasil survei arkeologis yang dilakukan Balai Arkeologi Ambon di Selaru menunjukan bahwa pulau ini memiliki potensi tinggi dalam kerangka studi arkeologi dan sejarah budaya. Lebih dari empatpuluh lokus yang ditinjau dengan karakteristik yang beragam. Dari jumlah tersebut terdapat lebih dari selusin situs yang dipandang paling potensial dan telah dideskripsikan di atas. Lebih jauh, secara umum, jika ditinjau dari karakteristiknya, situs-situs potensial di Pulau Selaru dapat dibagi dalam tiga kategori yaitu: pertama, kawasan karst dan situs gua hunian; kedua, situs pemukiman kuno; dan ketiga situs penguburan sekunder. Adapun hasil pengamatan pada masingmasing kategori situs dapat dijelaskan sebagaimana diuraikan di bawah ini.

\section{Kawasan Karst dan Situs Gua Hunian}

Secara umum Pulau Selaru memiliki karakter geologis yang khas dengan bentang luas kawasan karst. Kondisi ini dapat diamati dari keletakan situs-situs yang umumnya bertautan dengan bentang alam berciri karst. Mulai dari lokus pengamatan pertama di Desa Eliasa, yang terletak di bagian selatan Pulau Selaru, potensi kawasan karst ini langsung dapat diamati. Demikian halnya ketika bergerak lebih ke utara, kawasan kast juga ditemukan di desa Lingat dan sekitarnya. Selain khas dengan dataran tinggi, daerah ini juga memiliki sebaran gua yang cukup banyak. Persebaran ini konsisten hingga ke utara mencapai wilayah Desa Kandar dan Adaut. Di Kandar, sebaran ceruk di pesisir ditemukan dalam wilayah yang cukup luas dan berlanjut hingga mencapai wilayah Kora di Desa Adaut.
Salah satu implikasi alamiah bentang luas kawasan karst ini adalah keberadaan gua-gua yang tersebar di dalam lingkungan khas gamping ini. Kondisi ini ditemukan dengan sangat menonjol utamanya di bagian selatan Pulau Selaru, meliputi kawasan Desa Eliasa. Di sisi tenggara desa ini telah diidentifikasi kompleks gua Hoa Nugebusu yang cukup luas. Setidaknya terdapat dua titik gua yang sangat potensial di sini. Yaitu lokus yang diidentifikasi sebagai situs Gua Hoa Nugebusu 1 dan Gua Hoa Nugebusu 2. Karakteristik kedua gua ini serupa, yang memiliki pintu yang lebar dengan bilik yang lapang, intensitas sinar matahari baik dan lantai kering. Hasil pengamatan permukaan juga menemukan ragam temuan permukaan yang didominasi oleh fragmen tembikar. Hal mana menjadi indikasi awal adanya aktifitas okupasi di masa lalu. Kedua situs ini sangat layak untuk ditindaklanjuti utamanya dengan pendekatan ekskavasi untuk menemukan kronologi dan karakteristik benda budaya yang terdeposit.

Potensi serupa kiranya juga diidentifikasi di bagian tengah Pulau Selaru sebagaimana ditemukan pada Gua Usbob di Desa Lingat. Meski dari segi ukuran gua tidak selapang kompleks Gua Hoa Nugebusu di Eliasa, di Gua Usbob juga ditemukan jejak artefaktual berupa sebaran fragmen tembikar. Hal mana menjadi pijakan awal untuk aktifitas ekskavasi guna menemukan profil lapisan budaya dan kronologi situs.

\section{Situs Pemukiman Kuno Negeri Lama dengan megalitik}

Karakteristik kedua yang diidentifikasi pada situs-situs arkeologi di Selaru adalah sebaran luas situs-situs pemukiman kuno. Situs pemukiman kuno ini kiranya umum 
ditemukan di Asia Tenggara hingga Oseania. Termasuk di Maluku dan Kepulauan Tanimbar. Ciri khas situssitus ini adalah keletekan yang berada di dataran tinggi, memiliki lokasi yang minim atau sukar diakses. Umumnya hanya memiliki satu jalan menuju lokasi, dan memiliki karakter defensif sebagai sarana pertahanan sebagaimana ditunjukan oleh keberadaan tembok keliling yang memperkuat lokasi yang minim akses sebelumnya.

Hasil survei di Selaru menemukan bahwa semua desa yang disurvei memiliki situs-situs pemukiman kuno ini. Umumnya situs-situs ini telah ditempati lintas generasi. Dan mengacu pada tradisi tutur mulai ditinggalkan setelah persentuhan dengan masa kolonial. Ketika itu, kebijakan pasifikasi menyusul penerapan politik etis di penghujung abad ke-19 mendorong pemerintah kolonial untuk merelokasi masyarakat yang berdiam di lokasilokasi yang sukar diakses menuju daerah pesisir yang lebih terbuka dan mudah diakses.

Hasil studi arkeologis terkait situs-situs pemukiman kuno dengan karakteristik ini telah memberikan gambaran kronologis bahwa situssitus ini mulai berkembang pada awal masa sejarah dan mencapai puncaknya pada abad ke-14 hingga abad ke-17. Tesis yang umum diterima adalah bahwa kemunculan situssitus dengan karakteristik defensif ini terkait erat dengan meniningkatnya ekskalasi konflik dan perang antar komunitas di masa itu sebagai dampak perubahan iklim ekstrim yang berdampak pada keterbatasan sumber daya alam. Persaingan akses pada sumber-sumber penghidupan ini yang kemudian menjadi awal konfik dan perang yang bermuara pada tumbuh kembang situs-situs pemukiman berciri defensif (Lape, 2006).

Hasil survei di Selaru mengkonfirmasi sebaran luas situssitus ini di Kepulauan Tanimbar. Serupa dengan situs-situs sejenis di Yamdena dan pulau-pulau yang lebih ke utara, situs-situs berciri pertahanan juga menjadi ciri khas dari pemukiman kuno yang disebut sebagai negeri lama oleh masyarakat setempat. Mulai dari selatan hingga ke utara situs-situs ini teridentifikasi dan berasosiasi dengan identitas dan sejarah asal usul desa sebagaimana ditemukan di Eliasa, Weraing, Lingat, Kandar hingga Adaut. Menarik bahwa di situs pemukiman kuno Lakmodat di desa Lingat, masih ditemukan jejak-jejak tradisi megalitik sebagaimana diwakili oleh dolmen yang dikonfigurasi dalam bentang lahan pemukiman kuno.

\section{Situs Penguburan Sekunder}

Memperkuat tesis mengenai kemunculan situs pemukiman kuno sebagaiakibatkonflikdan perangadalah keberadaan situs-situs penguburan sekunder yang keletakannya seringkali berasosiasi dengan situs pemukiman kuno itu sendiri. Karakteristik khas dari situs pemukiman sekunder ini adalah bahwa di situs ini hanya ditemukan cranium atau bagian tengkorak dari manusia. Tidak ditemukan bagianbagian tubuh lain. Sejarah tutur masyarakat setempat di desa-desa yang disurvei umumnya memiliki kisah bahwa tengkorak-tengkorak ini adalah kepala musuh yang dipenggal sebagai bagian dari tradisi mengayau dan perang. Sumber-sumber etnohistori memang mengkonfirmasi mengenai sejarah konflik antar desa dan tradisi mengayau yang pernah berkembang di Kepulauan Tanimbar dan Pulau Selaru. Sebagaimana antara lain dituturkan oleh Drabbe dan Forbes. Data ini kiranya relevan dengan keberadaan 
situs-situs pemukiman kuno berciri defensif sebagai implikasi tingginya konfilk antar komunitas tersebut.

Saat ini situs-situs penguburan sekunder ini menjadi lokus memori sosial yang terkait denga sejarah desa dan komunitas. Difungsikan sebagai tempat sakral, situs-situs ini seringkali masih menjadi bagian dari kepercayaan lama yang secara terbatas masih dipraktekan, meski mayoritas penduduk telah memeluk agama nasrani. Hal ini dapat diamati dari keharusan melakukan ritual oleh para tetua sebelummengamati situssitus ini serta keberadaan aneka sesaji masyarakat yang ditempatkan di situssitus ini.

\section{Arah Studi Lanjutan dan Pengembangan Potensi}

Bercermin pada potensi arkeologi dan karakteristik situs-situs di atas, kiranya jelas bahwa Selaru sebagai pulau terdepan, kaya dengan potensi kepurbakalaan dan sejarah budaya. Karakteristik potensi yang dimiliki juga memiliki ciri yang bertautan dengan tema-tema studi arkeologi dan sejarah budaya dalam kawasan. Hal mana kiranya memberi ruang bagi arkeologi Pulau Selaru untuk ditinjau kembali dan dikembangkan lebih lanjut baik dalam kerangka studi-akademis arkeologi maupun pengembangan untuk tujuan yang lebih luas. Berikut beberapa aspek yang kiranya dapat ditindaklajuti dalam bingkai riset arkeologi serta pengembangan potensi.

\section{Pemetaan dan Ekskvasi Situs-Situs Pemukiman Kuno}

Survei yang dilaksanakan pada tahun 2013 secara umum telah mengidentifikasi situs-situs pemukiman kuno yang ada di selaru. Termasuk dalam kegiatan survei ini adalah ploting astronomis untuk mengamati sebaran situs serta pemetaan aspek bentuk situs dalam sketsa. Mengamati kembali sebaran luas dan profil situs yang cukup kompleks dengan keterkaitan dalam tema penelitian kawasan, kiranya dirasa perlu untuk melakukan pemetaan secara lebih komprehensif atas aspek formal situs terutama dalam kaitan dengan keletakan dalam bentang lahan dan asosiasi yang lebih rinci dengan lingkungan. Aktifitas ini kiranya dapat diperkaya dengan melakukan ekskvasi atau coring untuk melakukan pencuplikan dan uji petik sampel untuk kepentingan uji kronologi. Hal mana akan mempertegas kronologi situs dan memberikan gambar yang lebih jelas tentang proses tumbuh kembang situssitus di Selaru dalam kaitan dengan situs-situs serupa di kawasan sekitar.

\section{Sejarah Tutur}

Aspek kedua yang dapat didalami adalah menghimpun sejarah tutur masyarakat setempat. Serupa dengan tempat-tempat lain Kepulauan Tanimbar dan Maluku, tradisi menulis tidak dikenal di Selaru hingga kedatangan orang-orang Eropa. Sebagai implikasinya, pengetahuan masa lalu hanya diteruskan secara verbal melalui tradisi tutur. Termasuk dalam kaitan dengan asal usul masyarakat, proses migrasi, konflik dan perang hingga memori sosial terkait situs-situs arkeologi. Pengetahuan terkait sejarah tutur kiranya merupakan salah satu sumber data dipandang dapat memberi bobot dalam kerangka pengetahuan lokal dan memperkaya data arkeologi yang dikumpulkan. Meski memiliki potensi dari segi akademis, belum ada kajian yang secara khusus berupaya menghimpun pengetahuan sejarah tutur yang kini mulai langka ini. 
Ekskavasi di Situs Gua dan Pemukiman: Kronologi

Serupa dengan situs-situs pemukiman kuno, kawasan karst dengan ceruk dan gua di Selaru jelas memiliki potensi untuk ditindaklanjuti melalui studi arkeologi. Ragam temuan permukaan yang teridentifikasi di berbagai situs ceruk dan gua menjadi indikator aktifitas manusia masa lalu sekaligus penanda awal bagi kegiatan ekskavasi. Mengamati geografi Selaru yang menjadi pulau paling selatan di Maluku, yang berhadapan langsung dengan Australaia, pulau ini kiranya memiliki potensi untuk ditinjau dalam kerangka upaya menemukan jejakjejak migrasi manusia masa lalu dari daratan dan kepulauan asia tenggara menuju australia atau sebaliknya. Pencuplikan sampel untuk uji kronologi dan eksvaksi arkeologis kiranya menjadi pilihan paling relevan untuk menemukan kemungkinan yang lebih jauh atas tesis di atas. Termasuk penanganan objek-objek temuan dengan analisis laboratorium yang lebih mendalam.

\section{Monografi/ publikasi potensi purbakala pulau terdepan}

Aspek terakhir namun memiliki nilai paling penting kiranya melekat pada pengembangan segenap pengetahuan arkeologi dan sejarah budaya serta potensi kepurbakalaan yang ada di Selaru dalam kaitan dengan pengembangan wilayah ini sebagai salah satu pulau terdepan. Bagi masyarakat, kebutuhan-kebutuahan dasar seperti listirk, akses jalan, serta perhubungan dan fasilitas kesehatan tentu lebih mendesak. Meski demikian, bercermin pada antuasiasme dan semangat masyarakat dalam kegiatan survei, jelas bahwa ada kebanggaan dan harapan yang diletakan agar kekayaan sejarah budaya setempat dapat diangkat untuk lebih dikenal. Tentu, pilihan utama pasca aktifitas riset adalah publikasi ilmiah sebagaimana antara lain diwakili oleh tulisan ini. Publikasi atas kekayaan potensi pusaka juga telah dilakukan lewat media. Melalui aktifitas seperti ini, meski terbatas, sejatinya penelitian arkeologi telah menjadi jembatan untuk memberi tempat bagi kekayaan budaya di selaru dan pulau-pulau terdepan lain dalam ruang-ruand akademis nasional. Harapannya pun sederhana, bahwa pengetahuan masa lalu ini setidaknya dapat diabadikan dalam kerangka akademis. Harapan lebih jauh tentu saja agar lokus-lokus yang dipandang paling potensial, dapat diregistrasi sebagai situs cagar budaya baik dalam kerangka nasional, propinsi ataupun kabupaten. Hal mana akan menjadi langkah awal bagi kemungkinan pengelolaan yang lebih baik untuk segenap pusaka di tapal batas negara ini ke depan. 


\section{PENUTUP}

Pengelolaan pulau terdepan dan kawasan perbatasan telah menjadi isu yang mengemuka dalam pengelolaan wilayah negara selama lebih dari satu dekade terakhir. Dinamika tinggi kawasan tapal batas negara dengan berbagai kasus sengketa kiranya menjadi cermin untuk mengamati kondisi itu. Tak heran pemerintah kini semakin giat untuk mendorong pengembangan kawasan perbatasan guna memperkuat ketahanan embarkasi terdepan bangsa. Termasuk dalam pembangunan aspek kebudayaan di pulau-pulau terdepan.

Sebagai bidang ilmu yang bertautan dengan sejarah budaya, arkeologi di Indonesia kiranya memiliki tanggung jawab besar dan ruang yang luas untuk berpartisipasi aktif dalam mendorong pembangunan kebudayaan di wilayah perbatasan. Salah satunya melalui aktifitas penelitian untuk menemukenal potensi arkeologis dan sejarah budaya di tapal batas negara. Aktifitas riset dipandang dapat menjadi wahana untuk mengembangankan potensi sumberdaya budaya yang ada di wilayah perbatasan.

Sebagai rumah bagi 18 dari 92 pulau terdepan, arkeologi Maluku juga dihadapkan pada tanggung jawab serupa. Penelitian yang dilakukan di Pulau Selaru pada tahun 2013 ini, merupakan bagian dari upaya Balai Arkeologi Ambon untuk berkontribusi secara aktif dalam pengembangan kebudayaan di pulau-pulau terdepan di wilayah kerjanya. Hasil studi arkeologi awal ini memberikan hasil yang cukup menggembrikan. Sebagaimana bisa diamati dari sebaran luas potensi besar sumberdaya arkeologi yang teridentifikasi di Pulau Selaru. Lebih dari 40 lokus telah direkam dengan 12 situs yang dipandang memiliki potensi yang menjanjikan untuk ditindaklanjuti dan dikembangkan.

Dari 12 titik potensial tersebut dapat dibagi dalam tiga kategori yaitu situs kawasan karst dengan potensi gua dan ceruk hunian; situs pemukiman kuno serta situs-situs berciri penguburan sekunder. $\mathrm{Ke}-13$ situs ini terletak merata di desa-desa yang disurvei dan menunjukan keterkaitan dan konsistensi dengan situs-situs serupa dan relevansi dengan tema penelitian dalam kawasan. Menimbang riset ini merupakan studi perdana, maka ke depan diperlukan rangkaian aktifitas sebagai tindak lanjut yang dapat disarikan meliputi: pemetaan dan ekskavasi situs-situs pemukiman kuno, ekskavasi dan uji kronologi atas situs-situs gua dan ceruk hunian; pengembangan apsek kajian dengan menghimpun data etnohistori dalam bentuk sejarah tutur; publikasi baik ilmiah maupun jurnalistik atas segenap potensi yang telah direkam.

Harapan ke depan tentu saja, agar segenap pengetahuan arkeologi dan potensi sejarah purbakala yang telah dihimpun ini dapat menjadi titik awal untuk mendorong pengembangan potensi arkeologi dan sumberdaya budaya selaru dan pulau-pulau terdepan lainnya di Maluku. Pengembangan studi terkait budaya kiranya dapat menjadi aspek yang memberi keseimbangan dalam pembangunan dan pengembangan wilayah perbatasan, yang diharapkan tidak hanya bertumpu pada pembangunan infrastruktur dan sarana fisik, namun meluas pada pembangunan aspek sosial dan manusia. Termasuk pembangunan kebudayaan dan jati diri masyarkat untuk berdiri sejajar dalam identitas nasional sebagai bangsa. 


\section{DAFTAR PUSTAKA}

Aryanto, Gesit. 2009. "193 Titik Dasar, 92 Pulau Terluar" dalam Kompas 7 November 2009

Birdsell, J.B. (1977). "The Recalibration of a Paradigm for the First Peopling of Greater Australia", in J .Allen, J Golson, and R. Jones (eds.) Sunda and Sahul, p. 113-167.

De Jonge, $\mathrm{N}$ and van Dijk, T. 1995. Forgotten Islands of Indonesia: The Art and Culture of the Southeast Mollucas. Singapore: Periplus.

Lape, P. 2006. "Chronology of fortified sites in East Timor" In Journal of Island and Coastal Archaeology 1. pp. 285-297.

Le Bar, F. M. 1976. Insular Southeast Asia: Ethnographic Studies. Connecticut: New Haven.

Mc Kinnon, S. 1988. "Tanimbar Boats," dalam Islands and Ancestors: Indigenous Styles of Southeast Asia (eds J. P Barbier and D. Newton). New York: The Metropolitan Museum of Art. p. 152-169.

Miller, George. 2012. Indonesia Timur Tempo Doeloe. Jakarta: Komunitas Bambu

Retraubun, Alex. 2006. "Mengapa Terluar bukan Terdepan" dalam Kompas 20 September 2006.

Ririmasse, M. 2005. "Jejak dan Prospek Penelitian Arkeologi di Maluku" dalam Kapata Arkeologi Volume 1 No. 1. Balai Arkeologi Ambon.

Ririmasse, M. 2007. "Penelitian Arkeologi di Desa Lingat Pulau Selaru Kabupaten Maluku Tenggara Barat". Berita Penelitian Arkeologi Volume 3 No. 4. Balai Arkeologi Ambon.

Ririmasse, M. 2007b. "Fragmen Moko dari Selaru: Temuan Baru Artefak Logam di Maluku". Berita Penelitian Arkeologi Volume 3 No. 5. Balai Arkeologi Ambon.

Ririmasse, M. 2008. "Visualisasi Tema Perahu dalam Rekayasa Situs Arkeologi di Maluku". Naditira Widya Volume 2 No. 1. Balai Arkeologi Banjarmasin.

Ririmasse, M. 2008b. "Archaeology Goes to School: Mengemas Pengetahuan Warisan Budaya sebagai Muatan Lokal". Pertemuan IImiah Arkeologi XI Solo, 13-16 Juni 2008.

Ririmasse, M. 2010. “Arkeologi Pulau-Pulau Terdepan di Maluku: Sebuah Tinjauan Awal". Kapata Arkeologi Vol 6 No 12. Balai Arkeologi Ambon.

Ririmasse, M. 2011. "Laut untuk Semua: Materialisasi Budaya Bahari di Kepulauan Maluku Tenggara". Makalah disampaikan dalam Evaluasi Hasil Penelitian Arkeologi 2011. Banjarmasin.

Spriggs, M. 1998b. "Research questions in Maluku archaeology" dalam Cakalele 9: 49-62.

Tanudirdjo, D. 2005. "The dispersal of Austronesian-speaking People and the Ethnogenesis of Indonesian People" in Austronesian Diaspora and the 
Ethnogeneses of People in Indonesian Achipelago. Jakarta: LIPI Press.

Wibawa, Soni Prasetya. 2002. "Monumen Natar di Desa Sangliat Dol, Pulau Yamdena, Kepulauan Tanimbar, Maluku: Fungsi dan Kedudukannya dalam Konteks Pemukiman Tradisional". Skripsi. Universitas Gajah Mada Yogyakarta. Tidak diterbitkan.

Zuhdi, Susanto. 2006. "Mengapa Bukan Pulau Terdepan" dalam Kompas 8 September 2006. 